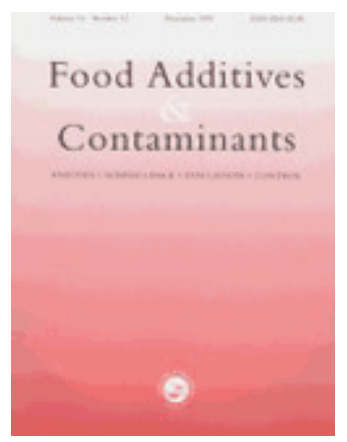

\title{
Development of a liquid chromatography-tandem mass spectrometric method for the simultaneous determination of tropane alkaloids and glycoalkaloids in crops
}

\begin{tabular}{|c|c|}
\hline Journal: & Food Additives and Contaminants \\
\hline Manuscript ID: & TFAC-2010-493.R1 \\
\hline Manuscript Type: & Original Research Paper \\
\hline $\begin{array}{r}\text { Date Submitted by the } \\
\text { Author: }\end{array}$ & 18-Apr-2011 \\
\hline Complete List of Authors: & $\begin{array}{l}\text { Jandric, Zora; IAEA, Joint FAO/IAEA Division of Nuclear Techniques } \\
\text { in Food and Agriculture } \\
\text { Rathor, Mohammad; IAEA, Joint FAO/IAEA Division of Nuclear } \\
\text { Techniques in Food and Agriculture } \\
\text { Švarc-Gajić, Jaroslava; University of Novi Sad, Department for } \\
\text { Applied and Engineering Chemistry } \\
\text { Maestroni, Britt; IAEA, Joint FAO/IAEA Division of Nuclear } \\
\text { Techniques in Food and Agriculture } \\
\text { Sasanya, James; IAEA, Joint FAO/IAEA Division of Nuclear } \\
\text { Techniques in Food and Agriculture } \\
\text { Djurica, Radenko; Public Health Institute of Republic of Srpska, } \\
\text { Department of Sanitary Chemistry } \\
\text { Cannavan, Andrew; IAEA, Joint FAO/IAEA Division of Nuclear } \\
\text { Techniques in Food and Agriculture }\end{array}$ \\
\hline Methods/Techniques: & Chromatography - LC/MS \\
\hline Additives/Contaminants: & Natural toxicants - alkaloids \\
\hline Food Types: & Cereals and grain, Animal feedingstuffs, Plants \\
\hline Abstract: & $\begin{array}{l}\text { A new, rapid and sensitive multiresidue method is reported for the } \\
\text { simultaneous determination of tropane alkaloids (tropine, atropine, } \\
\text { scopolamine, homatropine, anisodamine) and glycoalkaloids (a- } \\
\text { solanine, a-chaconine) in grains and seeds (wheat, rye, maize, } \\
\text { soybean, linseed). Dispersive solid phase extraction (DSPE) was } \\
\text { performed with } 0.5 \% \text { formic acid in acetonitrile/water and a }\end{array}$ \\
\hline
\end{tabular}




\section{SCHOLARONE Manuscripts}

mixture of magnesium sulphate, sodium chloride and sodium citrate. For a fast and effective clean-up procedure for oily matrices such as soybean and linseed, matrix solid phase dispersion (MSPD) C18 material was used to remove co-extracted non-polar components. No clean-up was necessary for less oily matrices following extraction. The analytes were separated by isocratic HPLC on a Chirobiotic V column and detected using a triple quadrupole mass spectrometer with electrospray ionization (ESI). All analytes were monitored in the positive ion mode. The method performance is presented in terms of linearity in the range $5-80 \mathrm{ng} / \mathrm{g}$ $(r 2=0.998)$, specifity, selectivity, accuracy (recoveries from 61$111 \%)$, precision ( $\mathrm{CV}<5 \%)$ and ruggedness. The limits of quantitation (LOQ) were in the range $2.2-4.9 \mathrm{ng} / \mathrm{g}$. 


\title{
Development of a liquid chromatography-tandem mass spectrometric method for the simultaneous determination of tropane alkaloids and glycoalkaloids in crops
}

\author{
Z. Jandrića ${ }^{a}$, M.N. Rathor ${ }^{\mathrm{a}}$, J. Švarc-Gajić ${ }^{\mathrm{b}}$, B.M. Maestroni ${ }^{\mathrm{a}}$, J.J. Sasanya ${ }^{\mathrm{a}}$, R. Djurica ${ }^{\mathrm{c}}$, A. \\ Cannavan $^{\mathrm{a}^{*}}$
}

${ }^{a}$ Food and Enviromental Protection Laboratory, FAO/IAEA Agriculture and Biotechnology Laboratories, Joint FAO/IAEA Division of Nuclear Techniques in Food and Agriculture, International Atomic Energy Agency, Wagramer Strasse 5, P.O. Box 100, 1400 Vienna, Austria;

${ }^{\mathrm{b}}$ Department for Applied and Engineering Chemistry, Faculty of Technology, University of Novi Sad, Novi Sad, Serbia;

${ }^{\mathrm{c}}$ Department of Sanitary Chemistry, Public Health Institute of Republic of Srpska, Banjaluka, Bosnia and Herzegovina;

* Corresponding Author: A.Cannavan@iaea.org

\begin{abstract}
A new, rapid and sensitive multiresidue method is reported for the simultaneous determination of tropane alkaloids (tropine, atropine, scopolamine, homatropine, anisodamine) and glycoalkaloids ( $\alpha$-solanine, $\alpha$-chaconine) in grains and seeds (wheat, rye, maize, soybean, linseed). Dispersive solid phase extraction (DSPE) was performed with $0.5 \%$ formic acid in acetonitrile/water and a mixture of magnesium sulphate, sodium chloride and sodium citrate. For a fast and effective clean-up procedure for oily matrices such as soybean and linseed, matrix solid phase dispersion (MSPD) $\mathrm{C}_{18}$ material was used to remove coextracted non-polar components. No clean-up was necessary for less oily matrices following extraction. The analytes were separated by isocratic HPLC on a Chirobiotic V column and detected using a triple quadrupole mass spectrometer with electrospray ionization (ESI). All analytes were monitored in the positive ion mode. The method performance is presented in terms of linearity in the range $5-80 \mathrm{ng} / \mathrm{g}\left(\mathrm{r}^{2}=0.998\right)$, specifity, selectivity, accuracy (recoveries from $61-111 \%)$, precision ( $\mathrm{CV}<5 \%)$ and ruggedness. The limits of quantitation (LOQ) were in the range $2.2-4.9 \mathrm{ng} / \mathrm{g}$.
\end{abstract}


Keywords: tropane alkaloids, glycoalkaloids, crops, liquid chromatography, tandem mass spectrometry

\section{Introduction}

Interest in natural toxins produced by fungi or plants has grown in recent years because of their toxicity and their effects on food and feed safety.

The terms tropane alkaloids and glycoalkaloids (GAs) refer to toxins naturally produced by the family Solanaceae (Nightshade), comprising over 100 genera and 3000 plant species found worldwide (European Food Safety Authority (EFSA) 2008). High concentrations of nightshade alkaloids have been found particularly in the genera: Datura; Datura stramonium (Jimsonweed), Datura ferox (Long Spined Thorn-apple), Datura innoxia (Thorn-apple or Moonflower), Atropa belladonna (Deadly Nightshade), Hyoscyamus niger (Black Henbane or Stinking Nightshade), Brugmansia (Angel's Trumpet) and Solanum nigrum (Black Nightshade). These plants are weeds of cultivated fields, waste land, barnyards, and other disturbed habitats. They produce variable amounts of tropane alkaloids and GAs and all parts of the plant, particularly the seeds, are potentially poisonous. Bulk commercial grains and seeds, such as wheat, rye, soybean, linseed, maize and solanaceous crops may be contaminated by non-grain impurities that coexist with the crop to be harvested (Papadoyannis et al. 1993; Friedman 2004; Naudé 2007). The most important tropane alkaloids are tropine, 1-hyoscyamine, scopolamine, atropine (a racemic mixture of d- and 1hyoscyamine), homatropine and anisodamine. The plant GAs are toxic steroidal glycosides (Laurila et al. 1999). The most common types of GAs, found in weed plants (Solanum nigrum, Solanum dulcamara) and important food sources such as Solanum tuberosum (potato), Solanum lycopesicum (tomato) and Capsicum (chilli, red, green or sweet pepper), are $\alpha$-solanine, $\alpha$-chaconine, $\alpha$-tomatine and dehydrotomatine.

Humans, horses, cattle, sheep, goats, pigs and poultry are all known to be affected by the alkaloids found in nightshades. Animals are, in general, less suceptible than humans to poisoning by alkaloids because of an esterase enzyme which allows more efficient biotransformation of atropine (Papadoyannis et al. 1993). Nightshade alkaloids block the activity of cholintesterase, which is involved in neurotransmission. If the activity of cholinesterase is strongly blocked, control of muscle movement becomes disrupted, and muscle twitching, trembling, breathing paralysis or convulsions can result. The nightshade 
alkaloids are associated with damage to the joints caused by inflammation and altered mineral status and can contribute to loss of calcium from bone and its excessive deposition in soft tissue. The alkaloids also have a direct irritant effect on the digestive system causing nausea and vomiting, diarrhoea and stomach cramps (Korpan 2004; Naudé 2007; EFSA 2008).

The GAs, $\alpha$-solanine and $\alpha$-chaconine, can be fatal to both humans and livestock (Korpan et al. 2004). In North Korea 382 people were affected following consumption of rotten potatoes, 52 of them hospitalised with symptoms including nausea, vomiting, facial oedema, cardiac arrest, and 22 deaths (McMillan and Thompson 1979). Several serious cases of human poisioning with food contaminated with tropane alkaloids and GAs have been documented, including those caused by consumption of hamburgers in Canada (CDC 1984), domestic food prepared with buckwheat flour in Slovenia (Perharic 2005), millet-carrot products in Austria (Fretz et al. 2007) and potatoes in Sweden, Cyprus and the UK (McMillan and Thompson 1979).

The estimated lethal doses of atropine and scopolamine in adults are greater than or equal to $10 \mathrm{mg}$ and greater than 2-4 $\mathrm{mg}$, respectively (Shervette et al. 1979; Hooper et al. 1979). Oral intake of $2-5 \mathrm{mg}$ of potato GAs per kilogram of body weight was reported to be toxic, and 3-6 mg was lethal for humans (Morris and Lee 1984). Pigs have been shown to be the most sensitive animal species to Datura poisoning, with a threshold limit of $1.5 \mathrm{mg}$ alkaloids/kg of feed (1.21 mg alkaloids/kg live weight) (Piva 1995).

In chemical terms, all alkaloids have at least one ring-like structure that contains a nitrogen atom. Tropane alkaloids are ester alkaloids resulting from the coupling of an organic acid (mostly tropic acid) with an amino alcohol (base). The parent base is the "tropane" base. The asymmetric $\alpha$-carbon of tropic acid allows the formation of two stereoisomers. Tropane alkaloids have in common a two-ringed structure characterized by a pyrrolidine and a piperidine ring sharing a single nitrogen atom and two carbon atoms. In this group the nitrogen atom at the end of the molecule is characteristically methylated. Thus, the common structural element of the tropane alkaloids is the bicyclic azabicyclo-octane skeleton (Dräger 2002; Naudé 2007). The structures of the main tropane alkaloids are shown in Figure 1.

Figure 1.

Steroidal alkaloids are characterised by the presence of an intact or modified steroid skeleton with nitrogen. $\alpha$-Solanine and $\alpha$-chaconine are glycosides which contain a non-polar steroid unit, a basic unit with either an indolizidine or oxa-azaspirodecane structure which together form the aglycone part, and a polar, water-soluble sugar moiety with three or four monosaccharides attached to the 3-hydroxyl group of the first ring of the aglycone. These two 
GAs have the same steroidal part of the molecule (aglycone), solanidine, but differ in the nature of the carbohydrate side chain with either a solatriose or a chacotriose sugar moiety attached to the solanidine (Figure 2) (Laurila et al. 1999; Eltayeb et al. 2003/4; Friedman 2004; Jensen et al. 2007).

Figure 2.

In Bavaria, Germany 686 feed materials were examined microscopically for the presence of Datura seeds between 1986 and 1988. Results showed up to $38.1 \%$ of the products were contaminated with parts of Datura seeds (EFSA, 2008). Soybean-based feeds were less frequently contaminated $(0.4 \%)$ than linseed products and the contamination of linseed products varied considerably between years (10.7, 29.0 and 51.4\%, respectively, in 1986, 1987 and 1988) (EFSA, 2008). Bucher et al. (1989) detected scopolamine in the range 0.1 to $33.3 \mathrm{mg} / \mathrm{kg}$ in single and mixed feeds contaminated with seeds of Datura. On the other hand, Papadoyannis et al. (1993) detected hyoscyamine in seed samples (-maize and soybean) at 3.4 $\mathrm{mg} / \mathrm{kg}$, while seeds contaminated with scopolamine were not detected. Contaminated seeds are usually subjected to processing before being incorporated into feeds for livestock. The intake of alkaloids can therefore be a function of the degree of contamination and the impact of processing. Tropane alkaloids and GAs are relatively stable and their levels are not affected by boiling, freeze-drying or dehydration; it is often not clear to what extent these processes remove or inactivate parts of the alkaloids (Friedman 2004; EFSA 2008).

The Scientific Panel on Contaminants in the Food Chain of the EFSA has reviewed the tropane alkaloids and concluded that they are undesirable substances in feed materials and feed (EFSA, 2008). There is no information available on carry-over of tropane alkaloids from feed into animal derived products under normal livestock production conditions. The European Union (EU) legislation sets a maximum permitted limit for weed seeds and unground and uncrushed fruits containing alkaloids, glycosides or other toxic substances, whether separately or in combination, in complete and complementary feedingstuffs (excluding feed ingredients), of $3000 \mathrm{mg}$ of seeds and/or fruit per $\mathrm{kg}$ of feedingstuff at $88 \%$ dry matter, or for Datura stramonium alone, $1000 \mathrm{mg} / \mathrm{kg}$ (European Community 2002). GAs are also recognized by EFSA as toxic compounds in a compendium of botanicals that have been reported to contain toxic, addictive, psychotropic, or other substances of concern (EFSA 2009).

Various analytical methods have been reported for determination of tropane alkaloids and GAs, such as enzyme-linked immunosorbent assay (ELISA) (Friedman et al. 1998), capillary electrophoresis (Mateus et al. 2000), micellar electrokinetic chromatography 
(Mateus et al. 2000), thin layer-chromatography (TLC) (Simonovska and Vovk 2000), gas chromatography-mass spectrometry (GC-MS) (Laurila et al. 1999; Miraldi et al. 2001; Balikova 2002), high-pressure liquid chromatography (HPLC) (Bucher et al. 1989; Papadoyannis et al. 1993; Cieri 2005; Kodamatani et al. 2005; Abreu et al. 2007; Jensen et al. 2007), liquid chromatography-mass spectrometry (LC-MS) (Matsuda et al. 2004; Breton et al. 2005; Siluk et al. 2007; Distl et al. 2009), liquid chromatography-tandem mass spectrometry (LC-MS/MS) (Xu et al. 1995; Chen et al. 2006).

None of the methods reviewed was developed and validated for the simultaneous determination of tropane alkaloids and GAs in grains and seeds. This may be because tropane alkaloids are usually produced by wild plants while GAs are mainly produced by cultivated plants (potatoes, tomatoes) and to a lesser extent by some wild plants (e.g. Solanum nigrum complex). However, there is a possibility of indirect contamination of food or feed products with alkaloid toxins, including through contamination of bulk comercial grains with toxins from weeds co-existing with the harvested crop, transfer and uptake of toxins from the environment (Jandric et al. in press), or from the use of potato waste to pelletize the combined grain components in animal feed production. Toxicological studies of these biologically active compounds demonstrate their importance for food and feed safety. A method for the analysis of a broad range of food and feed matrices for a range of tropane alkaloids and GAs is, therefore, desirable.

The aim of this study was to develop and validate a multiresidue method using LCMS/MS for the rapid and efficient determination of the major nightshade alkaloids (tropine, atropine, scopolamine, homatropine, anisodamine, $\alpha$-solanine and $\alpha$-chaconine) in crops. Such a method would facilitate the implementation of EFSA recommendations and allow simultaneous analysis of tropane alkaloids and GAs for research and risk assessment purposes.

\section{Materials and methods}

\section{Chemicals and reagents}

Atropine (d,l-hyoscyamine) (USP), l-scopolamine hydrobromide trihydrate ( $\geq 98 \%$, TLC), tropine hydrate ( $\geq 97 \%)$ and $\alpha$-solanine ( $\geq 99 \%$, TLC) were supplied by Sigma-Aldrich. Anisodamine (98.6\%, HPLC) and $\alpha$-chaconine (98.9\%, HPLC) were supplied by Oskar Tropitsch (Marktredwitz, Germany) while 1-hyoscyamine ( $\geq 99.9 \%$, HPLC) was purchased from Tokyo chemical industry (Tokyo, Japan). Deuterium labeled S-scopolamine- $\mathrm{d}_{3}$ hydrobromide (N-methyl- $\mathrm{d}_{3}$ ) trihydrate was purchased from Dr. Ehrenstorfer (Ausburg, 


\section{Instrumental conditions}

The chromatography was carried out using a Waters Alliance HPLC 2695 series (Waters, UK) equipped with a Chirobiotic V column ( 250 x $4.6 \mathrm{~mm}$ I.D., $5 \mu \mathrm{m}$ particle size) including a Chirobiotic V guard colum (2 $\mathrm{cm} \times 4.0 \mathrm{~mm}$ I.D., $5 \mu \mathrm{m}$ particle size) (Astec, Advanced Separation Technologies Inc., USA). The elution was achieved using mobile phase composed of $10 \mathrm{mM}$ ammonium formate in water/acetonitrile $(90: 10, \mathrm{v} / \mathrm{v}$, solvent A) and methanol/acetonitrile $(50: 50, \mathrm{v} / \mathrm{v}$, solvent $\mathrm{B})$ mixed in the ratio 20:80 (v/v, A:B). The assay took $16 \mathrm{~min}$ and was performed at $45( \pm 5)^{\circ} \mathrm{C}$ with a flow rate of $1 \mathrm{ml} / \mathrm{min}$. The column eluent was split using a 7:3 split ratio so that the flow entering the mass spectrometer was 300 $\mu 1 /$ min. The autosampler temperature was kept at $20( \pm 2)^{\circ} \mathrm{C}$ and the injection volume was 10 $\mu 1$. Detection and quantification were performed on a Micromass Quattro Micro triple quadrupole mass spectrometer (Waters, UK). MS/MS detection was performed in positive electrospray ionisation mode using multiple reaction monitoring (MRM) acquisition mode with inter-scan and inter-channel delays set at 0.1 and $0.02 \mathrm{sec}$, respectively. Nitrogen was used as a desolvation and cone gas (flow rates of $600 \mathrm{l} / \mathrm{h}$ and $50 \mathrm{l} / \mathrm{h}$, respectively) and argon as collision gas at 0.6 bar on a pressure regulator.

Radioactivity was determined using a Beckman LS 6000 liquid scintillation counter (LSC, Beckman Instruments, USA).

\section{Preparation of standard solutions and calibration curves}

Stock standard solutions (1 g/l) of tropane alkaloids (tropine, atropine, scopolamine, homatropine, anisodamine, scopolamine- $\mathrm{d}_{3}$ ) and GAs ( $\alpha$-solanine, $\alpha$-chaconine) were prepared individually in methanol and kept at $-25{ }^{\circ} \mathrm{C}$. From these individiual stock solutions, an intermediate standard mixture $(100000 \mathrm{ng} / \mathrm{ml})$ of all seven alkaloids was prepared. 
Working solutions were prepared at levels of 20,40,80, 160,320, 480 and $640 \mathrm{ng} / \mathrm{ml}$, by dilution in solvent $\mathrm{B}$ from the intermediate mixed standard solution. Matrix-matched calibrators were freshly prepared by spiking $0.5 \mathrm{ml}$ blank extract with working solutions. Calibration curves for each alkaloid ranged over 10, 20, 40, 80, 160, 240 and $320 \mathrm{ng} / \mathrm{ml}$ including internal standard (IS) at a constant concentration of $160 \mathrm{ng} / \mathrm{ml}$. The calibration range corresponded to concentrations of individiual alkaloids in samples between 2.5 and 80 ng/g. Calibration curves were constructed by plotting the ratio of the signal intensities (peak area) of the analyte and the IS (scopolamine- $\mathrm{d}_{3}$ ) versus the analyte concentration and results were processed using TargetLynx software (Waters, USA).

\section{Fortification for validation experiments}

Previously ground alkaloid-free grain and seed samples $(5 \mathrm{~g})$ were fortified at three different concentrations $(5,10$ and $40 \mathrm{ng} / \mathrm{g}$ of each alkaloid) by adding 25, 50, $200 \mu \mathrm{l}$ of a $1000 \mathrm{ng} / \mathrm{ml}$ standard mixture and $40 \mu \mathrm{l}$ of a $5000 \mathrm{ng} / \mathrm{ml}$ of the internal standrad (scopolamine$\mathrm{d}_{3}$ ). A full validation was carried out for wheat and soybean (three independent batches of each) on 3 different days and with 7 replicates at each level. For rye, maize and linseed the validation exercise was carried out only for the lowest level of alkaloids $(5 \mathrm{ng} / \mathrm{g}$ ).

\section{Extraction procedure}

Grain samples used for method development and validation purposes were purchased from a local grocery store. Samples were ground to a particle size of $<1 \mathrm{~mm}$ using a Cemotec 1090 sample Mill (Tecator, Sweden). The ground samples (5 g) were spiked and vortex-mixed for $30 \mathrm{~s}$ in $50 \mathrm{ml}$ Sarstedt tubes. The mixture was left to stand for $15 \mathrm{~min}$ before extraction to allow absorption of the spiking solution. Formic acid (0.5\%) in acetonitrile/water $(75: 25, \mathrm{v} / \mathrm{v})$ was then added $(20 \mathrm{ml})$. A mixture of magnesium sulphate $\left(\mathrm{MgSO}_{4}, 2 \mathrm{~g}\right)$, sodium chloride $(\mathrm{NaCl}, 0.5 \mathrm{~g})$, sodium citrate dihydrate $\left(\mathrm{C}_{6} \mathrm{H}_{5} \mathrm{Na}_{3} \mathrm{O}_{7} \cdot 2 \mathrm{H}_{2} \mathrm{O}, 0.5 \mathrm{~g}\right)$ and sodium hydrogencitrate sesquihydrate $\left(\mathrm{C}_{6} \mathrm{H}_{6} \mathrm{Na}_{2} \mathrm{O}_{7} \cdot 1.5 \mathrm{H}_{2} \mathrm{O}, 0.25 \mathrm{~g}\right)$ was added, the samples were shaken by hand (1 min) and centrifuged $\left(2600 \times \mathrm{g}, 4{ }^{\circ} \mathrm{C}, 10 \mathrm{~min}\right)$. Aliquots $(8 \mathrm{ml})$ of the wheat, rye or maize extract were evaporated to dryness under a stream of nitrogen using a TurboVap ${ }^{\circledR}$ LV evaporator (Zymark, Runcorn, UK) at $45^{\circ} \mathrm{C}$. In the case of soybean and linseed, an additional clean-up step was included to remove oily matrix components. MSPD C18 material was added to the extract $(0.05 \mathrm{~g}$ per $\mathrm{ml})$ mixed for $30 \mathrm{~s}$ by vortex, centrifuged $\left(1600 \mathrm{x} g, 4{ }^{\circ} \mathrm{C}, 10\right.$ min) and $8 \mathrm{ml}$ was taken for evaporation. The residues were dissolved in $0.5 \mathrm{ml}$ solvent $\mathrm{B}$, 


\section{Results and discussion}

Development of the analytical method

\section{MS/MS conditions}

Mass spectrometric MRM settings were optimized using a syringe pump loaded with a 500 ml Hamilton syringe to facilitate infusion experiments for each alkaloid. Direct infusion was done with analyte calibrants $(10000 \mathrm{ng} / \mathrm{ml})$ prepared in methanol and the syringe pump operated at a flow rate of $30 \mu \mathrm{l} / \mathrm{min}$. Stronger signal intensities for all analytes were observed in positive electropray mode $(\operatorname{ESI}(+))$, giving the protonated molecular ion $[\mathrm{M}+\mathrm{H}]^{+}$, than in negative-ion mode. Figure 3 shows the mass spectra obtained after fragmentation of the precursor ions. Atropine and 1-hyoscyamine (Figure $3 \mathrm{C}$ and D), although being isomers of the same molecule and giving the same product ions, required different spectrometric parameters to optimise the intensity of each ion, and produced different ion intensities in the fragmentation pattern. For samples in which the actual analyte is unknown, this would make confirmation of the analyte on the basis of ion ratios impossible. Therefore, upon screening samples that produce a peak matching the retention time of atropine/l-hyoscyamine and with the expected fragment ions, a second chromatographic method capable of separation of the 
enantiomers, such as that described by Siluk et al. (2007), would be required to unambiguously confirm the identity of the analyte as atropine or hyoscyamine and to quantify it.

Figure 3.

The optimized mass spectrometric parameters under ESI(+) were as follows: capillary voltage $2.99 \mathrm{kV}$, extractor $4 \mathrm{~V}$, RF Lens 0.3 V, LM 1 Resolution 14.4, HM 1 Resolution 15.2, Ion Energy 1 0.2, entrance -1, exit 2, LM 2 Resolution 13.6, HM 2 Resolution 14.8, Ion Energy 20.7 , source temperature $120{ }^{\circ} \mathrm{C}$, multiplier $650 \mathrm{~V}$, desolvation temperature $400{ }^{\circ} \mathrm{C}$. The MRM transitions with optimized parameters are shown in Table 1. The most abundant and stable fragment ion was used as quantifier ion, while the next most abundant ion was used as a qualifier ion.

\section{Table 1.}

\section{Chromatographic separation}

The primary objective of this study was to develop a simple, rapid method for screening multiple analytes belonging to the tropane alkaloid and GA groups in seeds, grains and similar food and feed matrices. It was considered desirable, but not essential, for such a method to achieve chromatographic resolution of the enantiomers of relevant compounds, such as atropine/hyoscyamine. 1-Hyoscyamine is present in nature as an active isomer that, during isolation, racemizes to atropine (Piva 1995). The possibility of enantiomeric resolution was, therefore, investigated. Several methods have been reported either for the separation of tropane alkaloids (Xu et al. 1995; Chen et al. 2006) or the GAs (Matsuda et al. 2004; Abre et al. 2007). The alkaloids are generally separated on columns with C18 stationary phases, using various isocratic mobile phases and gradient systems. Separation of optical isomers of atropine (d- and 1-hyoscyamine) has been reported using various methods, including capillary electrophoresis (Mateus et al. 2000), TLC (Bushan et al. 2001) and LC with chiral columns (Chirobiotic T2, Chirobiotic V, Chiral-AGP) (Cieri 2005; Breton et al. 2005; Siluk et al. 2007). Enantioselectivity mostly depends on the type of chirial stationary phase, binding sites between the phases and the mobile phase composition.

Successful separation of atropine enantiomers in less than 30 min was reported by Siluk et al. (2007) using a Chirobiotic V column $(25 \mathrm{~cm})$ on LC-MSD with reasonable enantioselective resolution $(\alpha=1.07)$, whilst the enantiomers could not be resolved on Chirobiotic T or Cyclobond I 2000 DNP stationary phases. This approach appeared promising and was adopted for our method development. Breton et al. (2005) reported that good resolution of the enantiomers was achieved using a Chiral-AGP column when using UV 
detection, but they were unable to obtain well-resolved peaks when using mass spectrometric detection. However, the objective of our study was to develop a simple and robust multianalyte method for both tropane alkaloids and GAs in a range of matrices and within a reasonable run time. This was not achievable using the conditions reported by Siluk et al (2007) or Breton et al. (2005) for enantiomeric separation. In developing the method presented in this paper, we decided to use a $25 \mathrm{~cm}$ Chirobiotic V column, as used by Siluk, to allow for the direct transfer of the method to counterpart laboratories in developing countries for use on a conventional HPLC sytem with UV detection as a screening method.

Different mobile phases were evaluated for separation of the atropine enantiomers as well as the other alkaloids. Efficient resolution of the atropine enantiomers was previously reported (Cieri 2005; Siluk et al. 2007) using a mobile phase consisting of methanol, acetic acid and triethylamine. Based on the mobile phases used by these groups, different ratios of acetic acid and triethylamine in methanol (100\%) were evaluated with the objective of achieving resolution of all target analytes within a reasonable run time. However, resolution of $\mathrm{d}$ - and l-hyoscyamine was not achieved and the positive ion abundances of the other analytes were depressed in the MS, probably due to the basic triethylamine modifier. Elution with $10 \mathrm{mM}$ ammonium formate (as ionization reagent) in a water/acetonitrile and methanol/acetonitrile mixture provided better results, giving good chromatographic resolution of the different analytes and higher sensitivity, but without enantiomeric separation. Because of the difficulty in achieving enantiomeric separation of d- and 1-hyoscyamine whilst retaining good sensitivity and resolution of the other analytes, acceptable ion abundances and a reasonable run time, it was decided to monitor d,l-hyoscyamine (atropine) as a single analyte for the method. Further work will be carried out in the future (resources permitting) to investigate the separation of the atropine enantiomers and to determine the level of racemization. The chromatographic separation achieved for the target analytes is shown in an ESI(+) LC-MS/MS MRM chromatogram of a matrix matched calibrator ( $80 \mathrm{ng} / \mathrm{g}$ ) in Figure 4.

Figure 4.

Whilst we did not achieve separation of the atropine enantiomers using chirobiotic columns using conditions that allowed the multi-analyte analysis, we found that the Chirobiotic V column produced much better resolution and sensitivity (in terms of improved peak width and height and signal to noise ratio) and long-term stability than the more conventional reversed phase columns that we tried (Phenomenex Gemini C-18, Atlantis and Waters XBridge). It was decided, therefore, to retain the Chirobiotic V column as the column of choice for this method. 


\section{Optimization of extraction solvent and cleanup}

The structural diversity and different chemical properties of the two groups of alkaloids included in the study caused difficulties in recovering all analytes at acceptable levels during sample preparation. Moreover, grain and seed samples are a complex matrix, rich in sugars, fat, proteins and pigments, which may interfere with alkaloids analysis. It was, therefore, necessary to carefully consider matrix interferences when developing the analytical method.

To the best of our knowledge, no methods for the simultaneous determination of a number of tropane alkaloids and GAs in crops have been reported. Bucher et al. (1989) and Papadoyannis et al. (1993) extracted hyoscyamine and scopolamine from feedstuff using dichloromethane and determined them by HPLC-UV. The selection of solvent in sample extraction is also of major importance to achieve efficient extraction. The sample preparation procedure for the extraction of alkaloids is usually based on the different solubilities of the alkaloid salts in comparasion to their free bases. Tropane alkaloids and GAs contain a tertiary amine which is protonated at lower pH (Dräger 2002; Jensen 2008). The relatively high solubility of the tropane alkaloids in water enables a selective extraction with aqueous acid, excluding lipophilic compounds (Dräger 2002). However, the solubility of GAs in water is relatively low (Jensen et al. 2007), making it difficult to coextract these compounds with the tropane alkaloids. Reported extraction procedures for tropane alkaloids in plants and biological fluids usually involve liquid-liquid extraction (LLE) (Xu et al. 1995; Miraldi et al. 2001) with non-miscible solvents or solid-phase extraction (SPE) (Balikova 2002; Chen et al. 2006). Most of the reported solvents used for GAs extraction are based on weak acidic solutions with the addition of other solvents or salts (Eltayeb et al. 2003/4; Matsuda et al. 2004; Kodamatani et al. 2005; Abreu et al. 2007; Machado et al. 2007).

In this study, for the first time, a mixture of $0.5 \%$ formic acid in acetonitrile/water $(75: 25$, v/v) with a salt mixture of $\mathrm{MgSO}_{4}, \mathrm{NaCl}, \mathrm{Na}_{2} \mathrm{H}$-citrate sesquihydrate and $\mathrm{Na}_{3}$-citrate dihydrate was employed as the best compromise for the simultaneous extraction of tropane alkaloids and GAs. Wheat was used as representative commodity to develop and optimise the extraction procedure.

During method development, an acidic mixture of methanol/ $0.25 \% \quad \mathrm{H}_{3} \mathrm{PO}_{4}$ was first evaluated as an extraction solvent at a sample to solvent ratio of $5 \mathrm{~g} / 20 \mathrm{ml}$ and extraction time of $30 \mathrm{~min}$. This mixture was previously used in mycotoxin analysis in wheat (Ware et al. 2000). The extracts obtained were filtered without any clean-up prior to determination by LCMS/MS. The extraction procedure was evaluated by spiking blank samples before extraction at a concentration of $200 \mathrm{ng} / \mathrm{g}$ of a mixture of tropane alkaloids and GAs. Calculations were 
performed by injecting matrix matched calibrators prepared in blank extract following the same extraction procedure. This extraction regime resulted in the presence of interfering matrix components in the extracts and very low recovery (about $20 \%$ for GAs).

The individual steps of the method extraction were optimised using radiolabelled ${ }^{14} \mathrm{C}$ atropine. The unique advantage of radioisotopes is that their behavior in a system is usually identical with that of their stable counterpart, and they can be identified easily with very high sensitivity by their characteristic radiation, even in extracts that have not undergone clean-up (Aysal et al. 2007). Isotopic tracers provide a very useful tool for following the pathway of substances through a chemical, physical or biological system. Using ${ }^{14} \mathrm{C}$-atropine, made it possible to determine the efficiency and follow up potential loses after each step of the method extraction (Table 2).

Table 2 .

Different mixtures of acetonitrile and water with and without the addition of formic acid and ammonium formate were used to optimize the alkaloids extraction and the extraction efficiency was compared (Table 2). DSPE has previously been successfully applied for pesticide analysis in oily matrices analysis (Aysal et al. 2007; Payá et al. 2007, Mol et al. 2008) in adaptaions of the QuEChERS (Quick, Easy, Cheap, Effective, Rugged and Safe) approach first published by Anastassiades et al. (2003). The added salts enhanced phase separation, enabling a larger volume of the extract to be taken for evaporation, thus improving sensitivity and realizing low limits of quantification. Reasonable recoveries (78-106\%) were obtained for all alkaloids in the spiked dry-matrices, confirming the high efficency of the selected extraction mixture. The extraction method was successfuly applied to other grains with no significant changes in recovery.

Table 3.

We found it unneccessary to apply any further clean-up after DSPE for wheat, rye and maize because the extracts were sufficiently clean and gave clear chromatograms. For soybean and linseed, the extracts were fatty and it was necessary to include a further clean-up step. Initial SPE experiments were carried out with $160 \mathrm{ng} / \mathrm{ml}$ of calibrants of the tropane alkaloids and GAs which corresponded to a concentration of $40 \mathrm{ng} / \mathrm{g}$ alkaloids in grains and seeds. Hydrophilic-lipophilic balance reversed-phase sorbent (Oasis, HLB, $200 \mathrm{mg}$ ) and polymeric reversed phase (Strata-X $33 \mu, 500 \mathrm{mg}$ ) cartridges were investigated. The results using this regime showed a loss of GAs.

Finally, DSPE using $\mathrm{MgSO}_{4}$, PSA and C-18 at different ratios was studied. Using $\mathrm{MgSO}_{4}$ and PSA, GAs were lost, possibly because of the sugar moiety in these alkaloids binding with 
the salts. The co-extracted fatty matrix compounds were successfully removed by silica-based C-18 material and recovery above 60\% was achieved for all selected alkaloids. DSPE cleanup with MSPD C-18 material allowed a rapid and rugged one-step sample purification.

\section{Evaluation of matrix effect}

Coeluting, undetected matrix components may reduce or enhance the ion intensity of the analytes and affect the reproducibility and accuracy of the assay (Mastuzewski et al. 2003). For the investigation of matrix effects on mass spectrometric detection, extracts of blank wheat, rye, maize, soybean and linseed were spiked at seven different concentration levels (each in duplicate) between 2.5 and $80 \mathrm{ng}$ of tropane and GAs per g of matrix, plus $40 \mathrm{ng} / \mathrm{g}$ of IS (scopolamine- $\mathrm{d}_{3}$ ). The results of the linear calibration functions (slopes calculated with IS correction) were compared with calibrants prepared in mobile phase B. The calculation of the signal suppression/enhancement (SSE) was done according to Sulyok et al. (2006), using the equation:

$$
\operatorname{SSE}(\%)=100 \times \text { slope }_{\text {spiked extract }} / \text { slope }_{\text {liquid extract }}
$$

The results obtained for SSE (\%) are shown in Figure 5.

Figure 5.

The data presented indicate that the most critical compounds are tropine and anisodamine and the huge signal variation from $100 \%$ (signal supression of up to $57 \%$ for anisodamine, $67 \%$ for tropine) indicates a significant matrix effect on these compounds in all matrices. Because of the high signal response at the lowest concentrations and the reasonable recovery, the method was still considered by the authors to be acceptable on the basis of sensitivity, linearity and recovery for these compounds over the range examined. Using matrix-matched calibration, the method could be extended to a large number of different matrices based on cereals, seeds and legumes.

Calibration curves were constructed by plotting the ratio of the signal intensities (peak area) of the analyte and the IS (scopolamine- $\mathrm{d}_{3}$ ) versus the analyte concentration

\section{Method validation}

\section{Selectivity and specifity}

The selectivity and specifity of the method were assessed by analyzing extracts from blank matrices (wheat, rye, maize, soybean and linseed). No endogenous peaks at the respective analyte retention times were observed in any of the extracts evaluated. Selectivity was 


\section{Limit of detection/quantification and linearity}

The limit of detection (LOD) and limit of quantification (LOQ) were estimated by injecting decreasing concentrations of matrix-matched calibrators and measuring the response at a signal-to-noise ( $\mathrm{S} / \mathrm{N})$ ratio of $\geq 3$ and $\geq 10$ for the LOD and LOQ, respectively. Using this approach, the LOD of all alkaloids ranged from 0.7 to $0.8 \mathrm{ng} / \mathrm{g}$ and the LOQ from 2.2 to 2.5 $\mathrm{ng} / \mathrm{g}$ in all grain and seed extracts except for tropine in soybean and linseed (LOD = 1.6 and $\mathrm{LOQ}=4.9 \mathrm{ng} / \mathrm{g})$.

The IS quantitation method was used for quantification of tropane alkaloids and GAs. In this study, we chose to use isotope labelled IS (scopolamine- $\mathrm{d}_{3}$ ) accompanied by matrixmatched calibrators to minimise possible matrix effects. Good linear relationships $\left(r^{2}>0.998\right)$ were achieved over the working range of $10-320 \mathrm{ng} / \mathrm{ml}$, which corresponds to a concentration of $2.5-80 \mathrm{ng}$ alkaloids per $\mathrm{g}$ of test sample.

\section{Recoveries}

The evaluation of recoveries was performed in the blank wheat, rye, maize, soybean and linseed matrices using fortification experiments. Table 4 shows the mean recoveries obtained for each of the tropane alkaloids and GAs at the spiking concentrations of 5, 10, $40 \mathrm{ng} / \mathrm{g}$ for wheat and soybean and $5 \mathrm{ng} / \mathrm{g}$ for rye, maize and linseed. The recovery was in the range 61$111 \%$, and the CV was $1-5 \%$. In this case, recoveries were independent of the analyte and the matrix indicating that the method could be applied in other matrices after confirming the method applicability at the lowest spiking level of $5 \mathrm{ng} / \mathrm{g}$.

Table 4. 


\section{Robustness/Ruggedness}

The robustness/ruggedness of an analytical procedure is a measure of its capacity to remain unaffected by small, but realistic variations in method parameters and provides an indication of its reliability during normal usage (Heyden et al. 2001). In this study the Youden approach, a fractional factorial design, to determine any critical points was employed (Youden et al. 1975). According to this approach, it is necessary to introduce several deliberate variations at once, rather than studying one variation at a time, keeping required time and effort to a minimum. Variations in factors were chosen that might typically be expected to occur in a routine working laboratory, a combination of which might possibly affect the method performance. The factors examined were (nominal values denoted by upper-case $A-F$, changes by lower-case $a-f): \boldsymbol{A}$ (extraction $\mathrm{pH}, 2.81), \boldsymbol{a}(2.86) ; \boldsymbol{B}$ (centrifuge speed, $1600 \times g, \boldsymbol{b}$ (1590 $x \mathrm{~g}$ ); $\boldsymbol{C}$ (evaporation temperature, $\left.40{ }^{\circ} \mathrm{C}\right), \boldsymbol{c}\left(44{ }^{\circ} \mathrm{C}\right) ; \boldsymbol{D}$ (buffer concentration, $\left.10 \mathrm{mM}\right), \boldsymbol{d}$ $\left(10.03 \mathrm{mM}\right.$ ); $\boldsymbol{E}$ (column temperature, $45{ }^{\circ} \mathrm{C}$ ), $\boldsymbol{e}\left(40{ }^{\circ} \mathrm{C}\right.$ ); and $\boldsymbol{F}$ (mobile phase flow, $1 \mathrm{ml} / \mathrm{min}$ ), $f(0.9 \mathrm{ml} / \mathrm{min})$. Samples spiked at a concentration of $20 \mathrm{ng} / \mathrm{g}$ were used in the test. The test confirmed that the method was not significantly influenced by the combined minor variations introduced and can be considered acceptably robust.

\section{Determination of alkaloids in samples from the market}

The proposed method was applied for the analyses of samples obtained from a local supermarket (cereals, feed and food seed products). Results $(n=3)$ showed that feed used for pigs and chicken were the most contaminated with: atropine (mean $\pm \mathrm{SD}, 12.7 \pm 0.7$ and $6.8 \pm 0.2 \mathrm{ng} / \mathrm{g}$, respectively), scopolamine $(12.1 \pm 1.1$ and $2.5 \pm 0.2 \mathrm{ng} / \mathrm{g}$, respectively), $\alpha-$ solanine $(6.1 \pm 0.5$ and $3.6 \pm 0.7 \mathrm{ng} / \mathrm{g}$, respectively) and $\alpha$-chaconine $(21.7 \pm 1.5$ and $9.6 \pm 0.8$ $\mathrm{ng} / \mathrm{g}$, respectively). In cattle and rabbit feed, only atropine $(6.5 \pm 0.6$ and $2.8 \pm 0.2 \mathrm{ng} / \mathrm{g}$, respectively) and scopolamine ( $9.8 \pm 0.7$ and $8.9 \pm 0.9 \mathrm{ng} / \mathrm{g}$, respectively) were detected while in feed for horses and wild animals none of the target alkaloids were detected. In food samples (wheat, rye, maize, mixed grain flour, corn flour, biscuits and crackers) alkaloids were not detected. The relative standard deviation figures reflect the heterogenicity of the alkaloids in the samples, rather than the method performance. Figure 6 shows MRM chromatograms of a naturally contaminated pig-feed sample.

Figure 6.

\section{Conclusion}

Alkaloids in food and feed are recognized as poisoning risks to man and animals, and the current interest of the scientific community in these substances is justified from scientific, 


\section{References}

Abreu P, Relva A, Matthew S, Gomes Z, Morais Z, Morais Z. 2007. High-performance liquid chromatography determination of glycoalkaloids in potatoes from conventional, integrated, and organic crop systems. Food Control 18:40-44.

Anastassiades M, Lehotay SJ, Štajnbaher D, Schenck FJ. 2003. Fast and easy multiresidue method employing acetonitrile extraction/partitioning and "dispersive solid phase extraction" for the determination of pesticide residues in produce. J AOAC Int 86:412-431.

Center for disease control and prevention. 1984. Datura poisoning from hamburger - Canada. MMWR 33 (20): 282-283.

Aysal P, Ambrus Á, Lehotay SJ, Cannavan, A. 2007. Validation of an efficient method for the determination of pesticide residues in fruits and vegetables using ethyl acetate for extraction. $\mathbf{J}$ Environ Sci Health B 42:481-490.

Balikova M. 2002. Collective poisoning with hallucinogenous herbal tea. Forensic Sci Int 128:50-52.

Breton D, Buret D, Clair P, Lafosse M. 2005. Chiral separation of atropine by highperformance liquid chromatography. J Chromatogr A 1088:104-109. 
Bushan R, Martens J, Arora M. 2001. Direct resolution of (+)-ephedrine and atropine into their enantiomers by impregnated TLC. Biomed Chromatogr 15:151-154.

Bucher E, Tischler J, Ludsteck M. 1989. HPLC-Bestimmung der Alkaloide (Scopolamin und Hyoscyamine) von Stechapfelsamen (Datura spec.) in Futtermittel. Landwirtschafttliche Forschung 42:293-309.

Chen H, Chen Y, Du P, Han F, Wang H, Zhang H. 2006. Sensitive and specific liquid chromatographic-tandem mass spectrometric assay for atropine and its eleven metabolites in rat urine. J Pharmaceut Biomed 40:142-150.

Cieri UR. 2005. Identification and estimation of the levo isomer in raw materials and finished products containing atropine and /or hyoscyamine. J AOAC Int 88(1):1-4.

Distl M, Sibum M, Wink M. 2009. Combination of on-line solid-phase extraction with LCMS for the determination of potentially hazardous glycoalkaloids in potato products, Potato Res 52:39-56.

Dräger B. 2002. Analysis of tropane and related alkaloids: Review, J Chromatogr A 978:1-35.

EFSA. 2008. Tropane alkaloids (from Datura sp.) as undesirable substances in animal feed. EFSA J 691:1-55.

EFSA. 2009. EFSA Compendium of botanicals that have been reported to contain toxic, addictive, psychotropic or other substances of concern. EFSA J 7(9):281.

Eltayeb EA, Al-Sinani SS, Khan IA. 2003/4. Determination of the glycoalkaloids a-solanine and a-chaconine levels in 18 varieties of potato (Solanum tuberosum L.) grown in Oman. Potato Res 46:57-66.

European Community. 2002. Directive 2002/32/EC of the European Parliament and of the Council of the 7 May 2002 on undesirable substances in animal feed. Off J Eur Union L 140, 30.5.2002, p. 10-21. 
European Community. 2002. 2002/657/EC: Commission Decision of 12 August 2002 implementing Council Directive 96/23/EC concerning the performance of analytical methods and the interpretation of results (Text with EEA relevance) (notified under document number C (2002) 3044). Off J Eur Union L 221, 17.8.2002, p. 8-36.

Fretz R, Schmid D, Brueller W, Girsch L, Pichler AM, Riediger K, Safer M, Allerberger L. 2007. Food poisoning due to Jimson weed mimicking Bacillus cereus food intoxication in Austria, 2006. Int J Infect Dis 11(6):557-558.

Friedman M, Bautista FF, Stanker LH, Larkin KA.1998. Analysis of potato glycoalkaloids. by a new ELISA kit. J Agr Food Chem 46:5097-5102.

Friedman M. 2004. Analysis of biologically compounds in potatoes (Solanum tuberosum), tomatoes (Lycopersicon esculentum), and jimson weed (Datura stramonium) seeds. J Chromatogr A 1054:143-155.

Heyden YV, Nijhuis A, Smeyers-Verbeke J, Vandeginste BGM, Massart DL. 2001. Guidance for robustness/ruggedness test in method validation. J Pharmaceut Biomed 24:723-753.

Hooper RG, Conner CS, Rumack BH. 1979. Acute poisoning from over-the-counter sleep preparations. J Am Coll Emerg Phys 8:98-100.

Jandrić Z, Rathor MN, Adu-Gyamfi J, Švarc-Gajić J, Mayr L, Resch C, Cannavan A. 2011. Wheat uptake and translocation of atropine ${ }^{14} \mathrm{C}$. Book of abstracts of the Saskatoon International Workshop on Validation and Regulatory Analysis, Saskatoon, Saskatchwan, Canada, 19-22 June 2011, in press.

Jensen PH, Harder BJ, Strobel BW, Svensmark B, Hansen HCB. 2007. Extraction and determination of the potato glycoalkaloid $\alpha$-solanine in soil. Int $\mathrm{J}$ Environ Anal Chem 87(12):813-824.

Jensen PH. 2008. Analysis and Fate of Toxic Glycoalkaloids from Solanum tuberosum in the Terrestrial Environment [dissertation]. [Copenhagen (DK)]: University of Copenhagen. 
Kodamatani H, Saito K, Niina N, Yamazaki S, Tanaka Y. 2005. Simple and sensitive method for determination of glycoalkaloids in potato tubers by high-performance liquid chromatography with chemiluminescence detection. J Chromatogr 1100:26-31.

Korpan YI, Nazarenko EA, Skryshevskaya IV, Martelet C, Jaffrezic-Renault N, El'skaya A. 2004. Potato glycoalkaloids: true safety or false sense of security? Trends Biotechnol 22(3):147-151.

Laurila J, Laakso I, Väänänen T, Kuronen P, Huopalahti R, Pehu E. 1999. Determination of soalnidine- and tomatidine-type glycoalkaloid aglycones by gas chromatography/mass spectrometry. J Agr Food Chem 47:2738-2742.

Machado RMD, Toledo MCF, Garcia LC. 2007. Effect of light and temperature on the formation of glycoalkaloids in potato tubers. Food Control 18:503-508.

Mateus L, Cherakoui S, Christen P, Veuthey JL. 2000. Enantioseparation of atropine by capillary electrophoresis using sulfated B-cyclodextrin: application to a plant extract. $\mathrm{J}$ Chromatogr A 868:285-294.

Matsuda F, Morino K, Miyazawa H, Miyashita M, Miyagawa H. 2004. Determination of potato glycoalkaloids using high-pressure liquid chromatography-electrospray ionisation/mass spectrometry. Phytochem Analysis 15:121-124.

McMillan M, Thompson JC. 1979. An outbreak of suspected solanine poisoning in schoolboys: Examination of criteria of solanine poisoning. Q J Med 48:227-243.

Miraldi E, Masti A, Ferri S, Comparini IB. 2001. Distribution of hyoscyamine and scopolamine in Datura stramonium. Fitoterapia 72:644-648.

Mol HGJ, Plaza-Bolaños P, Zomer P, de Rijk TC, Stolker AAM, Mulder PPJ. 2008. Toward a Generic Extraction Method for Simultaneous Determination of Pesticides, Mycotoxins, Plant Toxins, and Veterinary Drugs in Feed and Food Matrixes. Anal Chem 80:9450-9459. 
Morris SC, Lee TH. 1984. The toxicity and teratogenicity of Solanaceae glycoalkaloids, particularly those of the potato (Solanum tuberosum): A review. Food Aust 36(3):118-124.

Naudé TW. 2007. Veterinary Toxicology-Basic and Clinical Principles. Oxford (UK): Elsevier-Academic Press. Chapter 70, Datura spp. and other related plants; p. 892-906.

Papadoyannis IN, Samanidou VF, Theodoridis GA, Vasilikiotis GS, Van Kempen GJM, Beelen GM. 1993. A simple and quick solid phase extraction and reversed phase HPLC analysis of some tropane alkaloids in feedstuffs and biological samples. J Liq. Chromatogr 16(5):975-998.

Payá P, Anastassiades M, Mack D, Sigalova I, Tasdeln B, Oliva J, Barba A. 2007. Analysis of pesticide residues using the Quick Easy Cheap Effective Rugged and Safe (QuEChERS) pesticide multiresidue method in combination with gas and liquid chromatography and tandem mass spectrometric detection. Anal Bioanal Chem 16(7):1610-1617.

Perharic L. 2005. Mass tropane alkaloid poisioning due to backwheat flour contamination. Clinical Toxicology 43:413.Breton D, Buret D, Clair P, Lafosse M. 2005. Chiral separation of atropine by high-performance liquid chromatography. J Chromatogr A 1088:104-109.

Piva G, Piva A. 1995. Anti-nutritional factors of Datura in feedstuffs. Nat Toxins 3:238-241. Shervette RE, Schydlower M, Lampe RM, Fearnow RG. 1979. Jimson "loco" weed abuse in adolescents. Pediatrics 63:520-523.

Siluk D, Mager DE, Gronich N, Abernethy D, Wainer IW. 2007. HPLC-atmospheric pressure chemical ionization mass spectrometric method for enantioselective determination of R,Spropranolol and R,S-hyoscyamine in human plasma. J Chromatogr B 859:213-221.

Simonovska B, Vovk I. 2000. High-performance thin-layer chromatography determination of potato glycoalkaloids. J Chromatogr 903:219-225.

Ware GM, Price G, Carter L Jr, Eitenlimer RR. 2000. Liquid chromatographic preparative method for isolating ergot alkaloids, using a particle-loaded membrane extracting disk. J AOAC Int 83:1395-1399. 
Xu A, Havel J, Linderholm J, Hulse J. 1995. Development and validation of an LC/MS/MS method for the determination of L-hyoscyamine in human plasma. J Pharmaceut Biomed $14: 33-42$.

Youden WJ, Steiner E.H. 1975. Statistical Manual of the Association of Official Analytical Chemists, The Association of Official Analytical Chemists ed.; Arlington p.33-36, 70-71, 8283.

\section{FIGURE CAPTIONS}

Figure 1. Structure of tropine, homatropine, atropine, 1-hyoscyamine, scopolamine, anisodamine, scopolamine- $\mathrm{d}_{3}$ and ${ }^{14} \mathrm{C}$-atropine.

Figure 2. Structures of $\alpha$-chaconine, $\alpha$-solanine and solanidine (Abreu et al. 2007) 
Figure 3. Tandem mass spectrometry (MS/MS) spectra of tropane alkaloids and glycoalkaloids generated by electrospray ionization (ESI) and collision-induced dissociation. From top to bottom: tropine (A), homatropine (B), atropine (C), l-hyoscyamine (D), scopolamine (E), scopolamine- $\mathrm{d}_{3}$ (IS) (F), anisodamine $(\mathrm{G}), \alpha$-chaconine $(\mathrm{H})$ and $\alpha$-solanine (I).

Figure 4. ESI(+) LC-MS/MS MRM chromatograms of 2 product ions derived from each of the alkaloids at concentration of $80 \mathrm{ng} / \mathrm{g}$. From top to bottom: tropine, homatropine, atropine, anisodamine, $\alpha$-solanine, $\alpha$-chaconine, scopolamine- $\mathrm{d}_{3}$ (IS) and scopolamine.

Figure 5. The signal suppression/enhancement effect in wheat, rye, maize, soybean and linseed.

Figure 6. MRM chromatogram of a naturally contaminated pig-feed sample containing: atropine $(12.7 \pm 0.7 \mathrm{ng} / \mathrm{g}), \quad \alpha$-solanine $(6.1 \pm 0.5 \mathrm{ng} / \mathrm{g}), \quad \alpha$-chaconine $(21.7 \pm 1.5 \mathrm{ng} / \mathrm{g})$, scopolamine-d $\mathrm{d}_{3}$ (IS) $(40 \mathrm{ng} / \mathrm{g}$ ) and scopolamine $(12.1 \pm 1.1 \mathrm{ng} / \mathrm{g}$ ) (mean $\pm \mathrm{SD}, 2$ product ions derived from each of the alkaloids - from top to bottom). 
Table 1. MRM transitions with optimized parameters

\begin{tabular}{|c|c|c|c|c|c|c|}
\hline Compound & $\begin{array}{c}\text { Time window } \\
\text { (min) }\end{array}$ & $\begin{array}{l}\text { Precursorion } \\
\qquad[M+H]^{+}\end{array}$ & $\begin{array}{c}\text { Product ions } \\
(\mathrm{m} / \mathrm{z})\end{array}$ & $\begin{array}{c}\text { Cone } \\
\text { voltage }(V)\end{array}$ & $\begin{array}{l}\text { Collision } \\
\text { energy }(e V)\end{array}$ & $\begin{array}{l}\text { Dwell } \\
\text { time }(s)\end{array}$ \\
\hline \multirow[t]{2}{*}{ scopolamine } & $4.0-9.0$ & 304 & $137.9^{\mathrm{a}}$ & 40 & 26 & 0.01 \\
\hline & & & $156^{\mathrm{b}}$ & 40 & 17 & 0.01 \\
\hline \multirow[t]{2}{*}{ scopolamine- $\mathrm{d}_{3}$} & $4.5-9.5$ & 307.1 & $141.1^{\mathrm{a}}$ & 40 & 26 & 0.01 \\
\hline & & & $159^{\mathrm{b}}$ & 40 & 16 & 0.01 \\
\hline \multirow[t]{2}{*}{$\alpha$-chaconine } & $4.6-9.6$ & 852.5 & $98^{\mathrm{a}}$ & 40 & 51 & 0.01 \\
\hline & & & $706.2^{\mathrm{b}}$ & 40 & 44 & 0.01 \\
\hline \multirow[t]{2}{*}{$\alpha$-solanine } & $5.5-10.5$ & 868.4 & $98^{\mathrm{a}}$ & 54 & 60 & 0.05 \\
\hline & & & $398.2^{\mathrm{b}}$ & 54 & 55 & 0.05 \\
\hline \multirow[t]{2}{*}{ anisodamine } & $7.0-12.0$ & 306.1 & $140^{\mathrm{a}}$ & 26 & 24 & 0.01 \\
\hline & & & $90.8^{\mathrm{b}}$ & 26 & 27 & 0.01 \\
\hline \multirow[t]{2}{*}{ atropine } & $8.6-13.6$ & 290.2 & $92.9^{\mathrm{a}}$ & 45 & 32 & 0.05 \\
\hline & & & $124^{\mathrm{b}}$ & 45 & 23 & 0.05 \\
\hline \multirow[t]{2}{*}{ homatropine } & $9.0-14.0$ & 276.2 & $142^{\mathrm{a}}$ & 39 & 21 & 0.05 \\
\hline & & & $92.9^{\mathrm{b}}$ & 39 & 35 & 0.05 \\
\hline \multirow[t]{2}{*}{ tropine } & $10.5-15.5$ & 142.1 & $97.9^{\mathrm{a}}$ & 37 & 23 & 0.01 \\
\hline & & & $82.7^{\mathrm{b}}$ & 37 & 22 & 0.01 \\
\hline
\end{tabular}

\footnotetext{
${ }^{\mathrm{a}}$ quantifier ion
}

${ }^{\mathrm{b}}$ qualifier ion 
Table 2. ${ }^{14} \mathrm{C}$-Atropine recoveries $\left(\mathrm{R}_{\mathrm{A}}\right)$ of spiked wheat and soybean samples in the different mixture composition applied for extraction (water/solvent/acid) as determined by LSC (recovery $\pm \mathrm{SD}, \mathrm{n}=3$ ).)

\begin{tabular}{|c|c|c|c|c|c|}
\hline & Wheat & & Soybean & & \\
\hline & Extraction & Overall & Extraction & Cleanup & Overall \\
\hline Solvent $\%(v / v)$ & $R_{A}(\%)$ & & & $R_{A}(\%)$ & \\
\hline $\mathrm{ACN}(50)$ & $82 \pm 12$ & $81 \pm 3$ & & & \\
\hline $\mathrm{ACN} / \mathrm{CH}_{2} \mathrm{O}_{2}(50+0.5)$ & $56 \pm 9$ & $52 \pm 6$ & & & \\
\hline $\mathrm{ACN}(75)$ & $83 \pm 5$ & $81 \pm 12$ & & & \\
\hline $\mathrm{ACN} / \mathrm{CH}_{2} \mathrm{O}_{2}(75+0.25)$ & $85 \pm 5$ & $81 \pm 11$ & & & \\
\hline $\mathrm{ACN} / \mathrm{CH}_{2} \mathrm{O}_{2}(75+0.5)$ & $94 \pm 4$ & $94 \pm 2$ & $93 \pm 3$ & $96 \pm 5$ & $95 \pm 5$ \\
\hline $\mathrm{ACN} / \mathrm{CH}_{2} \mathrm{O}_{2}(90+1)$ & $88 \pm 3$ & $87 \pm 9$ & & & \\
\hline $\mathrm{ACN}(100)$ & $42 \pm 3$ & $25 \pm 3$ & & & \\
\hline
\end{tabular}


Table 3. Dependence of apparent recovery of spiked wheat samples on the composition of the water/solvent/acid mixture applied for extraction (recovery $\pm \mathrm{SD}, \mathrm{n}=3$ ).

\begin{tabular}{lccccccc}
\hline $\begin{array}{c}\text { Solvent } \% \\
(\mathrm{v} / \mathrm{v})\end{array}$ & $\mathrm{ACN}$ & $\mathrm{ACN} / \mathrm{CH}_{2} \mathrm{O}_{2}$ & $\mathrm{ACN}$ & $\mathrm{ACN} / \mathrm{CH}_{2} \mathrm{O}_{2}$ & $\mathrm{ACN} / \mathrm{CH}_{2} \mathrm{O}_{2}$ & $\mathrm{ACN} / \mathrm{CH}_{2} \mathrm{O}_{2}$ & $\mathrm{ACN}$ \\
tropine & $30 \pm 0$ & $45 \pm 3$ & $18 \pm 4$ & $36 \pm 4$ & $82 \pm 4$ & $74 \pm 6$ & $81 \pm 6$ \\
homatropine & $116 \pm 2$ & $94 \pm 4$ & $97 \pm 3$ & $58 \pm 7$ & $108 \pm 2$ & $109 \pm 6$ & $100 \pm 6$ \\
atropine & $112 \pm 2$ & $93 \pm 4$ & $106 \pm 3$ & $57 \pm 4$ & $108 \pm 3$ & $101 \pm 6$ & $90 \pm 4$ \\
scopolamine & $114 \pm 3$ & $76 \pm 5$ & $113 \pm 4$ & $72 \pm 5$ & $107 \pm 4$ & $102 \pm 4$ & $105 \pm 4$ \\
anisodamine & $84 \pm 3$ & $65 \pm 2$ & $70 \pm 5$ & $52 \pm 5$ & $108 \pm 5$ & $78 \pm 3$ & $83 \pm 5$ \\
a-solanine & $73 \pm 4$ & $65 \pm 4$ & $16 \pm 6$ & $33 \pm 3$ & $84 \pm 4$ & $29 \pm 4$ & $30 \pm 1$ \\
a-chaconine & $118 \pm 2$ & $76 \pm 8$ & $80 \pm 4$ & $58 \pm 7$ & $107 \pm 2$ & $49 \pm 4$ & $36 \pm 4$ \\
\hline
\end{tabular}


Table 4. Overview of average recoveries $(\mathrm{R}, \%)$ for each analyte on 3 validation days, at 3 fortification concentrations (5, 10 and $40 \mathrm{ng} / \mathrm{g}$ ) and coefficients of variation (CV, \%) performed in wheat and soybean $(n=7)$. For rye, maize and linseed, the values shown are for the lowest fortification concentration.

\begin{tabular}{|c|c|c|c|c|c|c|c|c|c|c|c|c|c|c|c|c|}
\hline & & \multirow{2}{*}{$\begin{array}{l}\text { Fortification } \\
\text { level }(\mathrm{ng} / \mathrm{g})\end{array}$} & \multicolumn{2}{|c|}{ tropine } & \multicolumn{2}{|c|}{ homatropine } & \multicolumn{2}{|c|}{ atropine } & \multicolumn{2}{|c|}{ scopolamine } & \multicolumn{2}{|c|}{ anisodamine } & \multicolumn{2}{|c|}{$\alpha$-solanine } & \multicolumn{2}{|c|}{ a-chaconine } \\
\hline & & & $R$ & $C V$ & $R$ & $C V$ & $R$ & $C V$ & $R$ & $C V$ & $R$ & $C V$ & $R$ & $C V$ & $R$ & $\mathrm{CV}$ \\
\hline \multirow{13}{*}{ Wheat } & & 5 & 78.6 & 2.0 & 104.6 & 1.5 & 102.9 & 2.0 & 99.0 & 2.0 & 95.8 & 1.6 & 79.0 & 2.9 & 75.8 & 1.2 \\
\hline & day 1 & 10 & 78.5 & 3.1 & 105.5 & 1.3 & 103.2 & 1.4 & 96.6 & 1.6 & 99.8 & 1.8 & 80.1 & 2.8 & 72.7 & 2.4 \\
\hline & & 40 & 79.2 & 2.6 & 107.0 & 1.7 & 100.6 & 1.5 & 105.7 & 1.8 & 105.3 & 2.0 & 82.0 & 2.8 & 86.4 & 2.2 \\
\hline & overall levels & day $1, \%$ & 78.8 & 2.5 & 105.7 & 1.5 & 102.2 & 1.6 & 100.4 & 1.8 & 100.3 & 1.8 & 80.4 & 2.8 & 78.3 & 1.9 \\
\hline & & 5 & 78.3 & 2.6 & 106.2 & 1.3 & 104.5 & 2.1 & 99.4 & 1.5 & 95.0 & 2.5 & 78.7 & 1.9 & 78.6 & 1.2 \\
\hline & day 2 & 10 & 77.7 & 2.1 & 108.2 & 0.5 & 104.3 & 1.4 & 96.6 & 1.8 & 103.1 & 1.1 & 82.0 & 1.9 & 80.8 & 1.4 \\
\hline & & 40 & 78.3 & 3.4 & 106.8 & 1.7 & 103.2 & 1.7 & 106.9 & 2.1 & 105.5 & 2.0 & 80.9 & 2.0 & 86.5 & 2.5 \\
\hline & overall levels & day $2, \%$ & 78.1 & 2.7 & 107.1 & 1.2 & 104.0 & 1.7 & 101.0 & 1.8 & 101.2 & 1.9 & 80.5 & 2.0 & 82.0 & 1.7 \\
\hline & & 5 & 78.0 & 3.4 & 102.9 & 1.3 & 104.9 & 2.1 & 99.9 & 2.1 & 96.0 & 1.8 & 80.1 & 2.6 & 80.7 & 1.6 \\
\hline & day 3 & 10 & 78.0 & 2.7 & 106.8 & 1.3 & 104.9 & 2.2 & 99.2 & 2.7 & 100.7 & 1.6 & 78.9 & 2.4 & 74.9 & 2.1 \\
\hline & & 40 & 79.4 & 2.9 & 104.9 & 1.9 & 105.7 & 1.6 & 104.8 & 3.8 & 105.5 & 1.1 & 79.5 & 2.7 & 85.0 & 1.2 \\
\hline & overall levels & day $3, \%$ & 78.5 & 3.0 & 104.9 & 1.5 & 105.2 & 2.0 & 101.3 & 2.9 & 100.7 & 1.5 & 79.5 & 2.6 & 80.2 & 1.6 \\
\hline & overall days 1 & $1-3, \%$ & 78.5 & 0.4 & 105.9 & 1.0 & 103.8 & 1.4 & 100.9 & 0.4 & 100.7 & 0.5 & 80.1 & 0.7 & 80.2 & 2.3 \\
\hline \multirow{13}{*}{ Soybean } & & 5 & 80.2 & 4.6 & 104.5 & 2.4 & 102.9 & 1.8 & 101.3 & 1.6 & 99.1 & 1.5 & 62.7 & 3.9 & 70.7 & 4.6 \\
\hline & day 1 & 10 & 82.0 & 4.6 & 102.9 & 2.1 & 106.0 & 2.0 & 103.6 & 2.8 & 103.4 & 1.7 & 61.8 & 2.2 & 73.7 & 3.4 \\
\hline & & 40 & 82.0 & 1.5 & 106.3 & 2.2 & 106.5 & 1.7 & 106.9 & 2.2 & 104.4 & 2.2 & 71.5 & 4.0 & 82.7 & 4.9 \\
\hline & overall levels & day $1, \%$ & 81.4 & 3.6 & 104.5 & 2.2 & 105.1 & 1.8 & 103.9 & 2.2 & 102.3 & 1.8 & 65.3 & 3.4 & 75.7 & 4.3 \\
\hline & & 5 & 78.8 & 1.9 & 105.6 & 2.2 & 101.6 & 2.4 & 105.7 & 2.8 & 102.2 & 1.3 & 63.2 & 5.6 & 73.2 & 4.8 \\
\hline & day 2 & 10 & 84.0 & 4.6 & 104.0 & 3.1 & 103.6 & 2.7 & 105.4 & 2.9 & 101.8 & 1.2 & 62.6 & 3.4 & 75.7 & 3.0 \\
\hline & & 40 & 82.0 & 4.7 & 106.1 & 2.2 & 103.6 & 2.8 & 102.6 & 2.2 & 104.4 & 2.9 & 63.2 & 3.2 & 81.7 & 2.6 \\
\hline & overall levels & day $2, \%$ & 81.6 & 3.7 & 105.2 & 2.5 & 102.9 & 2.6 & 104.6 & 2.6 & 102.8 & 1.8 & 63.0 & 4.1 & 76.9 & 3.5 \\
\hline & & 5 & 83.0 & 3.8 & 104.4 & 3.1 & 102.0 & 3.0 & 101.5 & 2.2 & 104.7 & 2.9 & 63.9 & 4.4 & 75.6 & 3.2 \\
\hline & day 3 & 10 & 78.0 & 5.1 & 104.3 & 3.5 & 101.5 & 3.2 & 106.5 & 2.4 & 104.8 & 2.9 & 61.8 & 3.0 & 73.0 & 2.8 \\
\hline & & 40 & 81.0 & 5.2 & 105.0 & 3.1 & 103.4 & 3.4 & 105.2 & 2.4 & 102.9 & 1.3 & 62.6 & 3.1 & 83.3 & 4.0 \\
\hline & overall levels & day 3, \% & 80.7 & 4.7 & 104.6 & 3.2 & 102.3 & 3.2 & 104.4 & 2.3 & 104.1 & 2.4 & 62.8 & 3.5 & 77.3 & 3.3 \\
\hline & overall days 1 & $1-3, \%$ & 81.2 & 0.6 & 104.8 & 0.4 & 103.4 & 1.5 & 104.3 & 0.3 & 103.1 & 0.9 & 63.7 & 2.2 & 76.6 & 1.1 \\
\hline \multirow{4}{*}{ Rye } & day 1 & & 78.4 & 0.9 & 100.3 & 2.6 & 99.8 & 2.8 & 102.1 & 1.4 & 78.3 & 3.5 & 84.3 & 2.8 & 101.9 & 2.9 \\
\hline & day 2 & 5 & 77.2 & 2.5 & 103.8 & 1.9 & 105.4 & 1.6 & 106.1 & 0.6 & 80.4 & 2.3 & 81.1 & 3.2 & 102.1 & 2 \\
\hline & day 3 & & 76.5 & 1.5 & 102.1 & 0.7 & 102.3 & 1.1 & 107.4 & 0.8 & 79.2 & 4.2 & 82.9 & 2 & 103.7 & 1.5 \\
\hline & overall days 1 & $1-3, \%$ & 77.4 & 1.2 & 102.1 & 1.7 & 102.5 & 2.7 & 105.2 & 2.6 & 79.3 & 1.3 & 82.8 & 1.9 & 102.6 & 1.0 \\
\hline \multirow{4}{*}{ Maize } & day 1 & & 78.5 & 1.8 & 105.3 & 1.5 & 105.1 & 2.8 & 100.9 & 2.4 & 76.9 & 1.2 & 100.1 & 0.8 & 103.5 & 1.8 \\
\hline & day 2 & 5 & 79.1 & 1.6 & 105.8 & 2.1 & 103.5 & 1.8 & 101.5 & 1.8 & 79.1 & 3.4 & 99.3 & 2.4 & 105.8 & 0.8 \\
\hline & day 3 & & 79.9 & 2.6 & 106.5 & 1.9 & 104.4 & 2.1 & 102.4 & 3.4 & 77.5 & 1.5 & 102.3 & 1.7 & 104.6 & 1.1 \\
\hline & overall days 1 & $1-3, \%$ & 79.2 & 0.9 & 105.9 & 0.6 & 104.3 & 0.8 & 101.6 & 0.7 & 77.8 & 1.5 & 100.6 & 1.5 & 104.6 & 1.1 \\
\hline \multirow{4}{*}{ Linseed } & day 1 & & 71.8 & 3.4 & 100.2 & 2.4 & 108.8 & 4.5 & 100.6 & 1.5 & 98.4 & 2.1 & 60.4 & 1.9 & 80.9 & 4.5 \\
\hline & day 2 & 5 & 78.2 & 4.7 & 106.6 & 3.5 & 100.3 & 3 & 102.8 & 3.4 & 99.1 & 3.9 & 62.2 & 0.9 & 84.5 & 3.6 \\
\hline & day 3 & & 76.3 & 4.8 & 104.6 & 4.2 & 104.4 & 4.8 & 98.3 & 2.6 & 102.3 & 1.9 & 61.1 & 2.2 & 78.3 & 4.9 \\
\hline & overall days 1 & $1-3, \%$ & 75.4 & 4.4 & 103.8 & 3.2 & 104.5 & 4.1 & 100.6 & 2.2 & 99.9 & 2.1 & 61.2 & 1.5 & 81.2 & 3.8 \\
\hline
\end{tabular}


Figure 1.<smiles>CN1[C@H]2CC[C@@H]1C[C@H](O)C2</smiles>

tropine<smiles>CN1C2CC[C@@H]1C[C@@H](OC(=O)C(CO)c1ccccc1)C2</smiles>

homatropine<smiles>CN1C2CCC1CC(OC(=O)[C@H](CO)c1ccccc1)C2</smiles>

atropine<smiles>CN1C2CCC1CC(OC(=O)C(CO)c1ccccc1)C2</smiles>

I-hyoscyamine<smiles>CN1C2CCC1CC(OC(=O)[C@H](CO)c1ccccc1)C2</smiles>

scopolamine<smiles>CN1C2CC(OC(=O)C(CO)c3ccccc3)CC1C(O)C2</smiles>

anisodamine<smiles>[R]OC(=O)N1C2CCC1CC(OC(=O)[C@H](CO)c1ccccc1)C2</smiles>

scopolamine- $d_{3}$<smiles>CN1C2CCC1CC(OC(=O)C(CO)c1ccccc1)C2</smiles>

atropine ${ }^{14} \mathrm{C}$ 
Figure 2.
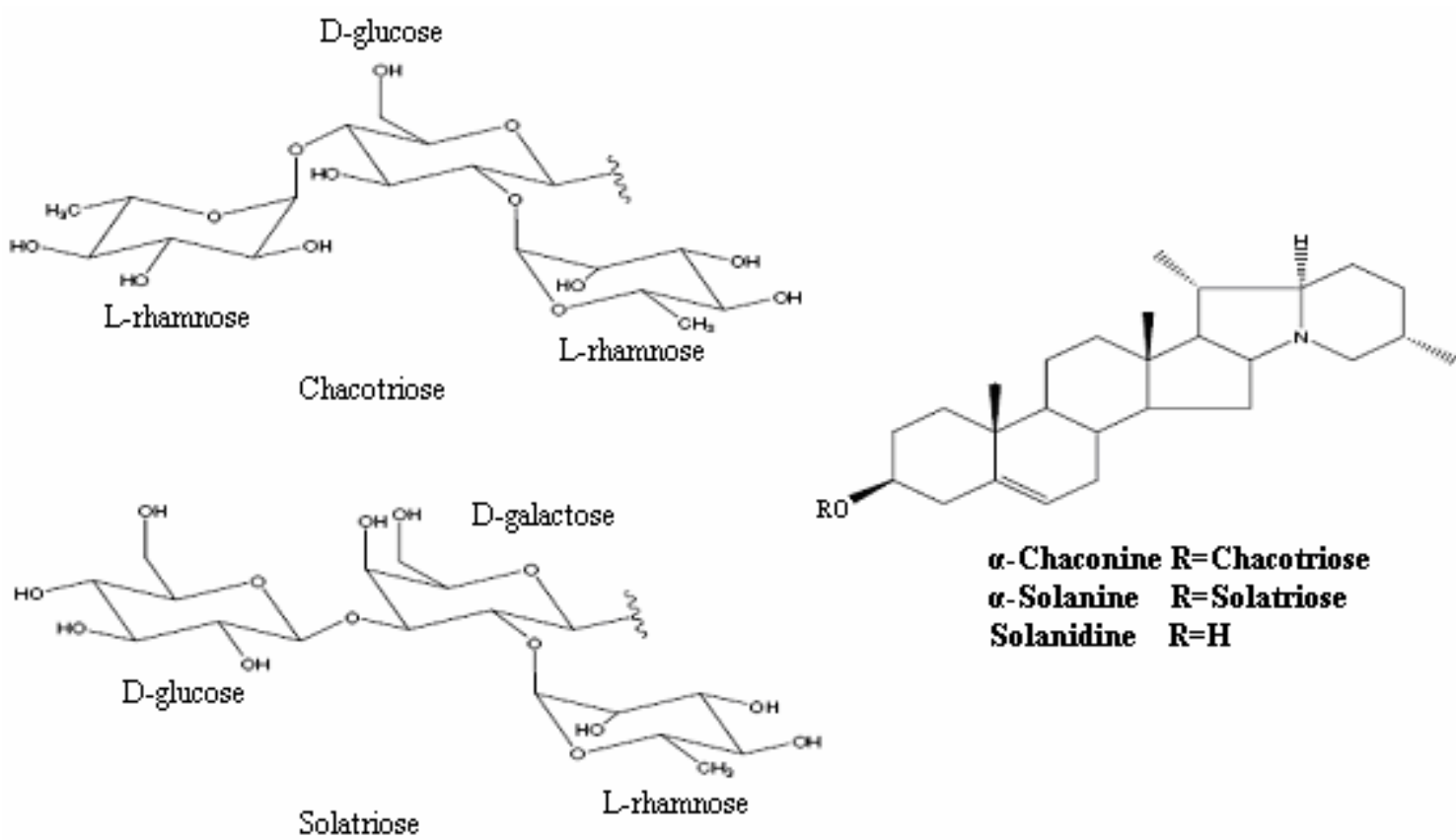
Figure 3
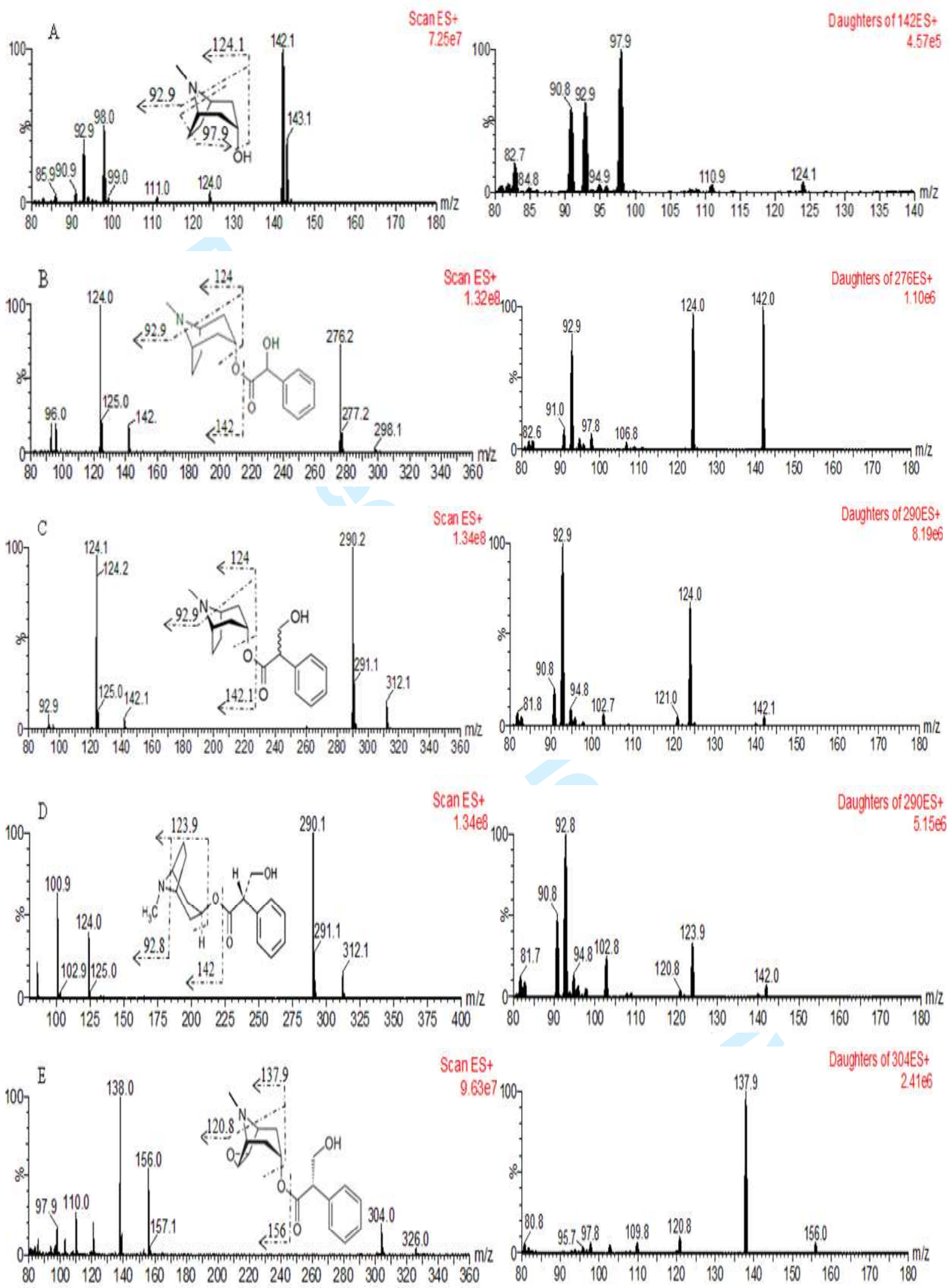

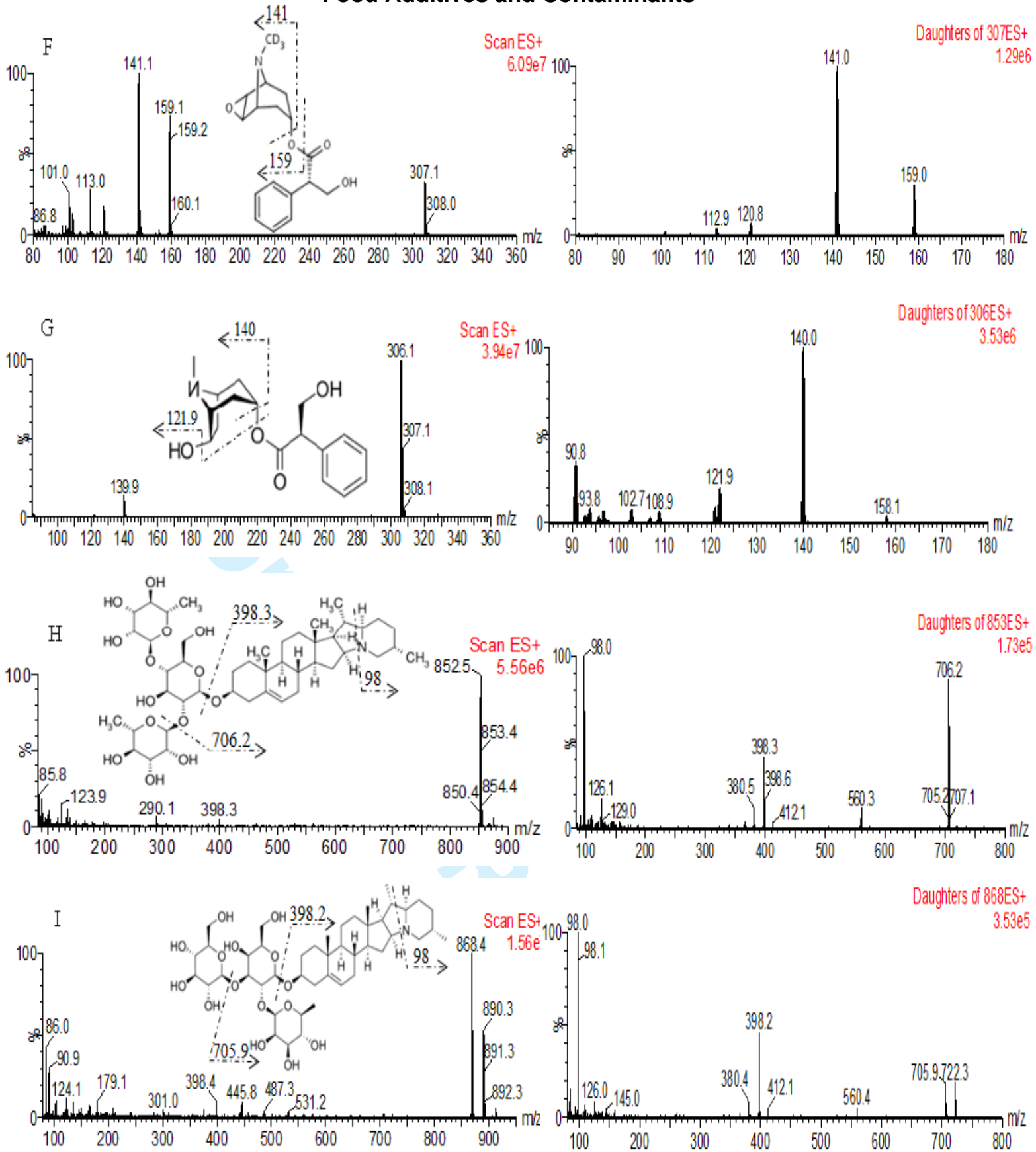
Figure 4.

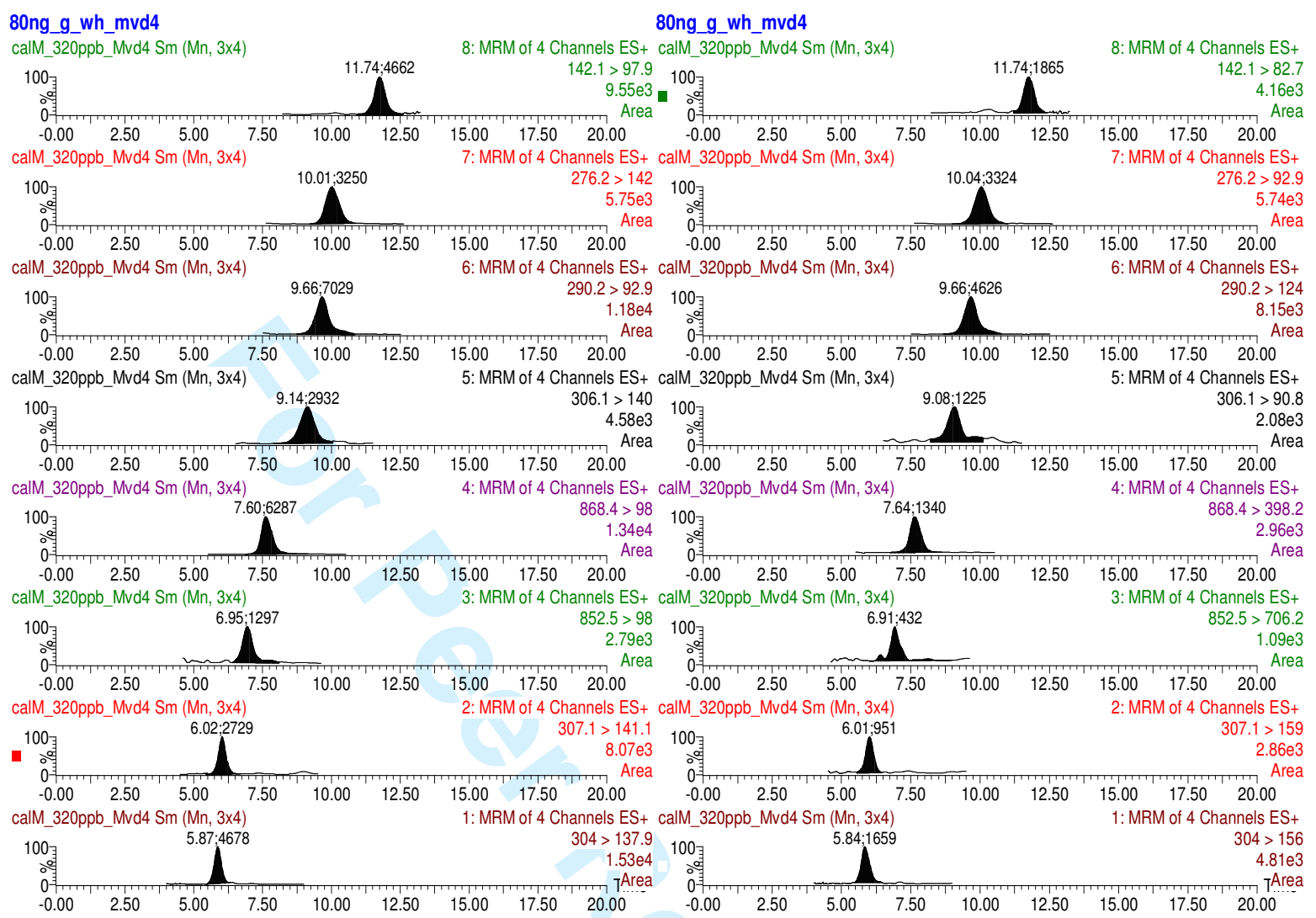


Figure 5.

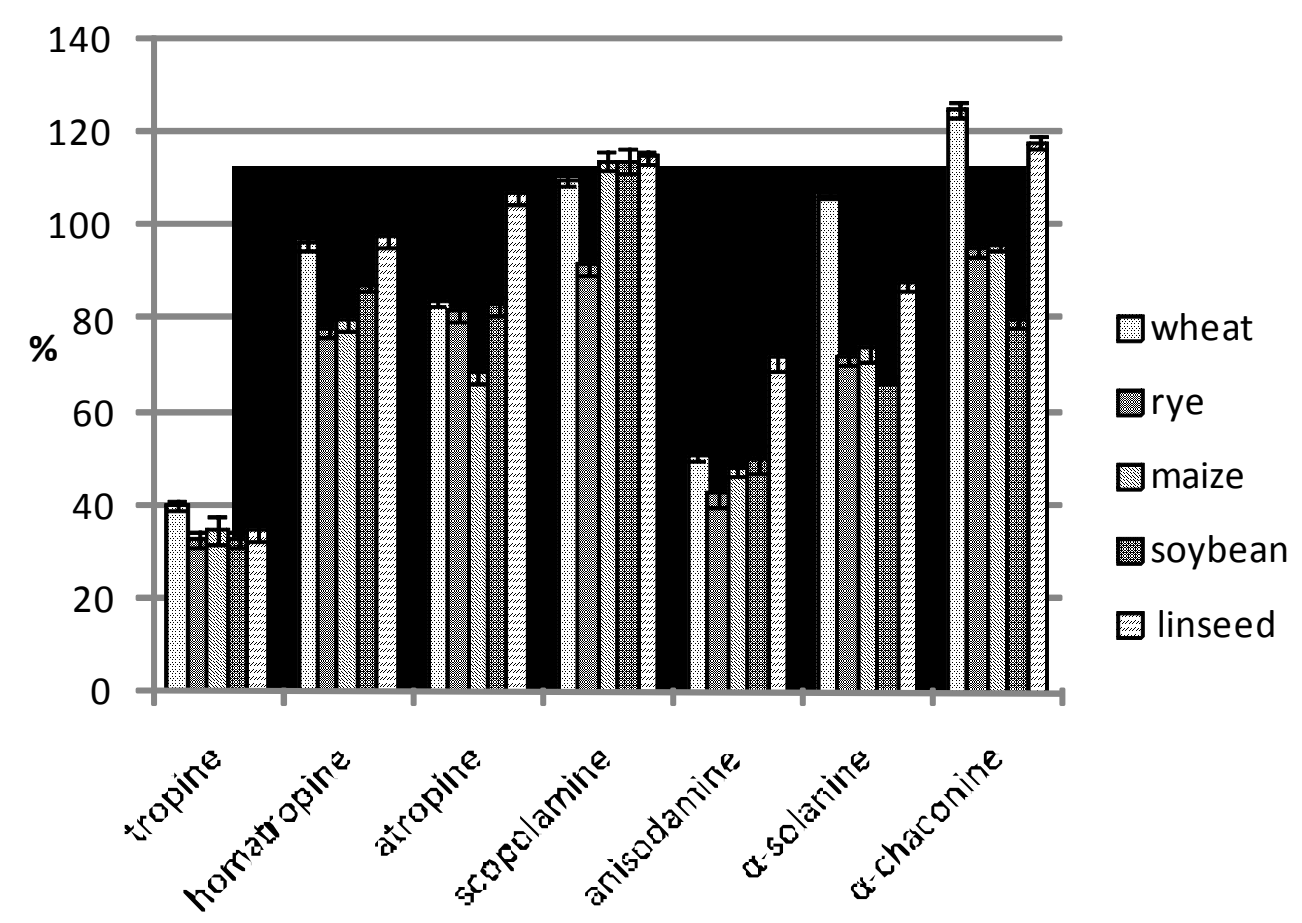

1

2

5

6

7

8

9

10

11

12

13

14

15

16

17

18

19

20

21

22

23

24

25

26

27

28

29

30

31

32

33

34

35

36

37

38

39

40

41

42

43

44

45

46

47

48

49

50

51

52

53

54

55

56

57

58

59

60 
Figure6.

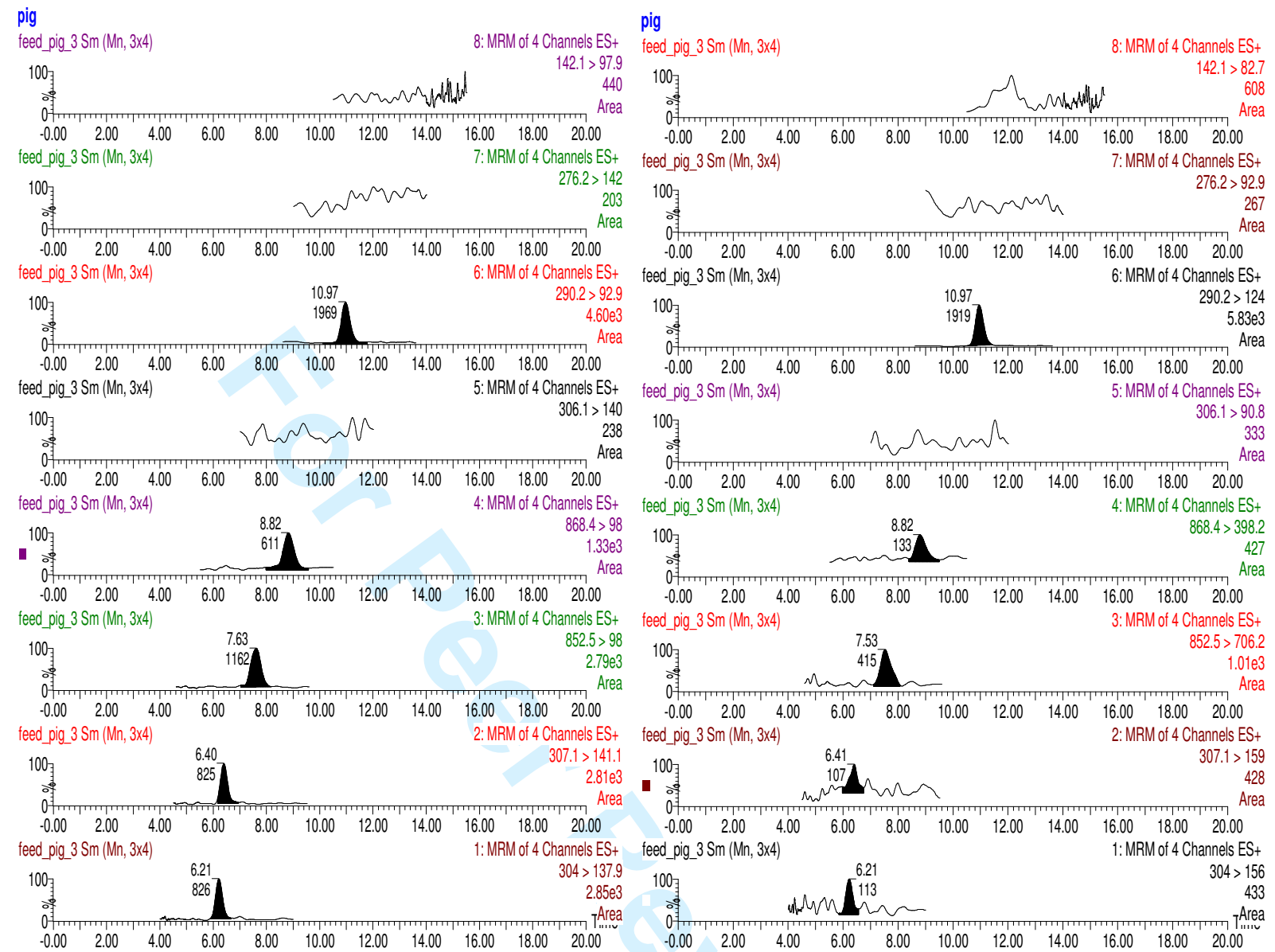

